clearly be to the advantage of both science and labour if the Congress were represented upon research boards and research associations concerned with industrial developments. The human factor in industrial progress has often been neglected in the past, and by bringing representatives of labour into close association with scientific and inventive work, the degrading results of some of their past applications to industry may be avoided.

\section{Racial Doctrine}

A NEW periodical publication with the title Races et Racisme is devoted to the record of current development in the application of theories of race to the doctrine of nationalism, with special reference to Germany (office of publication, 47 rue de Miromesnil, Paris VIIIe, price $1 \mathrm{fr}$.). Its main object is to keep the French people abreast of the progress of a movement of supreme importance in the world of to-day, upon which, it is thought, they are not sufficiently well informed. It should also prove valuable to those who desire first-hand and trustworthy information in readily accessible form of the increasing restrictions and penalties which are being imposed on freedom of thought and scientific and intellectual development in the nationalist-socialistic State. The utility of such a publication must clearly depend upon its freedom from the taint of the selective activity of the propagandist. The names which appear on the lists of the Comité de Patronage and the Comité Directeur are a guarantee that an objective impartiality will be exercised in the selection of material for publication. The lists include such well-known names as M. Gabriel Hanotaux, Prof. Lucien LévyBruhl, Prof. Paul Pelliot, Prof. G. Bouglé, P. Maurice Leenardt, le Comte Jean de Pange, and Prof. Paul Rivet, with Prof. E. Vermeil as one of two secretaries. Races et Racisme, of which numbers will appear at two-monthly intervals, will represent the trend of German thought in racial doctrine by verbatim reports, or full abstracts, of official documents, new laws and regulations, official pronouncements, articles and speeches of authority, as well as by analyses of books and a record of relevant events-all, as a rule, without comment, except when further explanation is considered necessary.

AN example of the commentary which the editorial body considers appropriate is afforded by the opening article, which runs through the two numbers before us and is still in progress. This is an exposition of the development of racial ideas in Germany by M. Edmond Vermeil. It begins with Leibniz and Herder and the concepts of the eighteenth century, and shows how the Germanic idea has progressed from the universalism of the philosopher to the Pan. Germanism upon which the doctrine of 'race' and 'blood' has been engrafted to implement Hitlerian nationalism. M. Vermeil, who takes a broad and philosophic view of his subject, will, in his later instalments, demonstrate how and why what appears to be no more than a political manœuvre, when judged by its objective, must necessarily permeate and transform activities, apparently remote from the political arena when functioning freely, to produce 'German' art, a 'German' science and a 'German' religion. It is to be noted, however, that the sweeping official claims for purity of race and the coincidence of Nordic and Aryan are so far abandoned that Prof. Oswald Kron of Tübingen is permitted to say that there are five or six races among the German people, while he claims for them a psychological unity.

\section{Native Lands in South Africa: A "New Deal"}

Considerable progress has been made in the provision of additional reserves for the native population of South Africa since the passing of the Native Lands Act, which was promulgated in August, 1936. Up to July last, according to a dispatch from the Cape Town correspondent of The Times, which appears in the issue of September 3, $£ 800,000$ has already been spent on the purchase of farms from Europeans. The farms which have been bought up to the present are mostly situated in the Transvaal, where the need for native land is greatest, as this is the principal area of native location on European farms, a practice which will not be permitted in future. The land is being allotted to the natives and settlement will proceed as the present European holders vacate. They have been permitted to remain in possession until after their harvest, and land is being provided for them elsewhere. Under the provisions of the Native Trust and Land Act, 1936, the South African Native Trust, representing the Government, is authorized to acquire 7,250,000 morgen (about $15,000,000$ acres) of lands for native use. It is anticipated that the work of settling the native on these lands, which will now go on steadily, will occupy a period of several years. It is elear, however, that if the situation is not taken in hand drastically, and the conditions which prevail on native lands, not only in South Africa, but also in territories to the north, are allowed to continue unchecked, a situation similar to that for which the present measures are intended to be a remedy will again arise before many years have passed, and probably then be more difficult to meet.

THE present deplorable condition of the existing native reserves and the agitation and discontent to which the shortage of native lands has given rise is not entirely due to overpressure of population, though this has been an important factor. Traditional methods of native agriculture and grazing, of which the ill effects were negligible when a practically unlimited area allowed freedom of movement and gave exhausted soil an opportunity to recover, have led, under the system of European restriction of boundaries and suppression of tribal raids, to a general impoverishment of the land, which has further deteriorated through the erosion consequent on the overstocking which follows from the Bantu regard for cattle as a sole and almost sacrosanct form of wealth. Since the passing of the Act, the Native Affairs Commission has been busily engaged in framing a policy which is intended to remedy these 